\title{
AZ ÁTALAKULÓ NAGYKOVÁCSI
}

\author{
(The Changing Nagykovácsi)
}

\author{
CSAPÁK ALEX
}

\section{Kulcsszavak:}

szuburbanizáció Nagykovácsi zártkertek mentális településkép

A tanulmányban egy, Nagykovácsiban végzett lakossági kérdöives felmérés legfontosabb eredményei jelennek meg. Nagykovácsi lélekszáma a szuburbanizációnak köszönhetõen az elmúlt húsz évben majdnem megkétszerezödött. A falu átalakult. A beköltözök és az öslakosok között ma jól dokumentálható szakadék tátong, mely legplasztikusabban a faluról alkotott mentális kép tekintetében rajzolódik ki.

\section{Bevezetés}

Nagykovácsi a Budapestet övezö, fokozatosan szuburbanizálódó településgyủrü tagja. A község számos - a nagyvárosból kiköltözők számára többnyire vonzó jellemzővel bír: a Budai-hegyvidék legmagasabban fekvő települése, az erdőségek szinte teljesen körülölelik, zsákfalu jellegének köszönhetően nincs átmenő forgalom. A nagyváros zsúfolt, zajos környezetétöl megcsömörlött családok számára ezért vált - már az 1970-es évektöl kezdve - „menekülési” célponttá az akkor még kicsiny falu. Kezdetben a zártkert-parcellázások, később a szuburbanizáció keretében zajló bevándorlás formálta át a község arculatát, társadalmát.

A lakossági kérdőives felmérés elsődleges célja a Nagykovácsiban „öslakosként” élö, illetve oda „szuburbán lakosként” betelepülő népesség jellemzőinek vizsgálata volt, ugyanakkor igyekeztünk feltárni a község átalakulásának egyéb vonatkozásait (pl. épületállomány változása) és a szuburbanizáció okait is.

\section{A kérdöives felmérés módszertani háttere}

Magyarországon - Nyugat-Európához viszonyítva - viszonylag késỏn jelent meg a lakossági szuburbanizáció folyamata, a nagyvárosokból való tömeges kiköltözés csupán az 1980-as évek dereka óta dokumentálható. Az elmúlt húsz évben számos kutató vizsgálta a szuburbanizáció hátterében meghúzódó okokat a fỏváros, illetve a vidéki nagyvárosok környezetében (pl. Dövényi-Kovács 1999; Bajmóczy 2000; Hardi 2002).

A Nagykovácsira vonatkozó kérdőives felmérés közvetlen előzménye a DövényiKovács szerzöpáros által 1997-ben végzett - 19 föváros környéki településre kiterjedő - kutatás volt. Munkánk során az ő általuk szerkesztett kérdőiv módositott változatát használtuk. A megkérdezendök körét azonban - szemben Dövényivel és Kováccsal kiterjesztettük az őslakosnak tekinthetö háztartásokra is (Dövényi-Kovács 1999). 
A felmérés során házról-házra járva igyekeztünk - nyolc terepgyakorlatozó másodéves geográfus hallgató ${ }^{1}$ közremüködésével - információkat gyüjteni a község háztartásairól. A válaszadás természetesen önkéntes, a válaszadók kiválasztása véletlenszerú volt, arra azonban törekedtünk, hogy a község teljes területét - minden utcáját - reprezentálja a kutatás. Válaszadóink 360 kérdőivet töltöttek ki; a kérdőivek közül 159 reprezentálja az őslakosnak tekintett háztartásokat, 201 pedig a szuburbán beköltözöket.

Mivel Nagykovácsi lakosságát a második világháborút követően kitelepítették, nem volt egyértelmú, hogy kiket tekinthetünk a faluban őslakosoknak. A kérdőívek feldolgozásakor végül úgy soroltuk két csoportba válaszadóinkat, hogy őslakosnak tekintettük a Nagykovácsiba 1985 elött beköltözöket, illetve az 1985 után a falun belül költözöket, a szuburbán betelepülö lakosok körébe pedig azokat a válaszadókat soroltuk, akik 1985 után érkeztek a faluba (több mint 90\%-uk a fövárosból költözött Nagykovácsiba).

\section{Nagykovácsi a statisztikák tükrében}

A második világháború elött Nagykovácsi németajkủ község ${ }^{2}$ volt, az 1945 után kiürített faluba felvidéki menekültek és alföldi gazdálkodók telepedtek le. A község - a folyamatos beköltözések ellenére is - csak 1976-ban érte el a háború előtt regisztrált lélekszámot (2883fö).

\section{1. ÁBRA}

Nagykovácsi vándorlási egyenlege 1985 és 2005 között (fö)

(Balance of Migration in Nagykovácsi between 1985 and 2005)

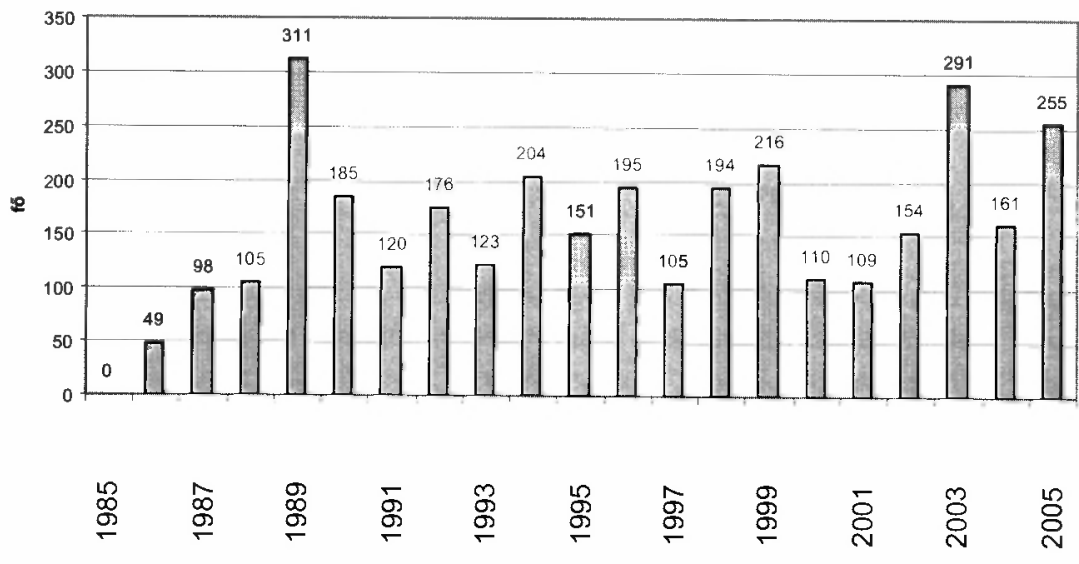

“A 2002 utáni adatok Nagykovácsira és Remeteszőlősre vonatkoznak.

Forrás: A KSH adatai alapján, saját szerkesztés. 
Nagykovácsi külterületén az 1970-es években közel 2000 zártkertet $^{3}$ parcellázott ki a községi tanács, a telkeket jórészt fővárosiak vásárolták meg. A hegyoldalak néhány év alatt beépültek nyaralóházakkal, és nyáron, illetve a hétvégeken már ekkor budapestiek tömege népesítette be a községet. Az 1980-as évek közepétől már a szuburbanizáció jegyében - a falu állandó lakossága is rohamosan gyarapodni kezdett; 1990 után nem volt olyan év, amikor a település vándorlási egyenlege ne mutatott volna legalább 100 fös pozitívumot (1. ábra). Nagykovácsi lélekszáma

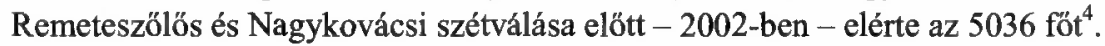

A község demográfiai mutatói is visszatükrözik a szuburbanizáció hatásait. A korszerkezet viszonylag fiatalos. A község öregedési indexe - a 2001-es népszámlálás idején - mindössze $50 \%$ volt, miközben a fövárosban messze $100 \%$ felett járt. A lakosság nem csak fiatalos, hanem jól is képzett: a nagykovácsiak fele legalább középfokú végzettséggel rendelkezik, negyede pedig felsőfokú képzettséggel bír.

A szuburbanizáció nem hagyta érintetlenül a falu külső megjelenését sem. Az utolsó két népszámlálás - 1990 és 2001 - között 538 lakóházzal gyarapodott a község. A négyszobás lakások aránya $12 \%$-ról $40 \%$-ra, az összkomfortos lakások aránya $46 \%$ ról 76\%-ra nött! A település peremén új házsorok, településrészek nőttek ki a földból, az egykori zártkertek állandó lakosokkal népesültek be. Felmérésünk idején - 2005ben - a Nagy-Szénás-hegy lábánál és a Kálváriadomb oldalában négyszáz frissen kimért elöközmüvesített telken éppen kezdett kibontakozni egy újabb beépitési/betelepülési hullám.

\section{A szuburbanizáció helyi mozgatórugói}

A kérdőíves felmérés során használt kérdések egy része a Nagykovácsiba költözés okait igyekezett feltárni. Arra kerestünk választ, hogy miért hagyták el fỏvárosí lakóhelyüket, és miért ebben a faluban kerestek új otthont a település szuburbán bekőltözői. A válaszok alapján egyértelmủen a környezet terheltsége (zaj, levegöszennyezés stb.), illetve a helyigény volt a legfontosabb taszító és vonzó tényező. Az 1985 óta Nagykovácsiba költözők 35\%-a említette az előző lakóhelyről való elkőltözés indokaként a környezeti problémákat, 27\%-uk az igényeiknek nem megfelelö, túl kicsi lakást. A Nagykovácsiba költözés indokai között messzemenően uralkodott a kellemes lakókörnyezet (a válaszadók 57\%-a említette), illetve a családi ok - gyermeknevelés, házasságkötés - $(33 \%)$.

Érdekes, a szuburbán beköltözők összetételének, preferenciáinak változására utaló eredményeket kaptunk azáltal, hogy a községbe érkezőket két csoportra (hullámra) tagoltuk. A szuburbanizáció első időszakában (1985-1994) Nagykovácsiba költözők körében még meglehetősen nagy súllyal estek latba az elöző lakóhelyröl való elköltözés indokai között az olyan „hagyományos” okok, mint az önálló háztartás létrehozására való törekvés (21\%), önálló tulajdonszerzés (22\%), munkahelyváltoztatás (7\%); a terhelt lakókörnyezet taszító mivoltát viszont aránylag kevesen említették (25\%). A községbe 1995 után betelepülök esetében viszont ezek az indo- 
kok - az önálló háztartás létrehozására való törekvés (14\%), az önálló tulajdonszerzés $(13 \%)$, a munkahely-változtatás ( $1 \%)$ - jelentősége drasztikusan csökkent, a környezet terheltségének taszitó hatása viszont karakterisztikusan megnött (41\%). A beköltözök két időcsoportja a Nagykovácsiba költözés indokai tekintetében is határozott különbségeket mutatott. A beköltözök második hulláma számára határozottabban vonzó tényezőnek számított a kellemes lakókörnyezet (az első hullámnál $43 \%$, a másodiknál $64 \%$ említette), vagy a javuló lakáskörülmény. A munkahelyi ok teljesen jelentỏségét veszítette a második hullám esetében (első csoportnál 12\%, másodiknál 3\%), illetve érdekes módon csökkent a kedvező vételi lehetőség jelentősége (14\%-ról 11\%-ra).

A szuburbán lakosság összetételének változására (a változás irányára) utalhat, hogy az előzó lakóhely jellegére adott válaszokban is jelentős eltéréseket mutatott a vizsgált két időcsoport. A szuburbanizáció első szakaszában még 23\% volt a panel lakótelepekről és $47 \%$ a sor- és tömbházakból a nagykovácsi családi házakba költözők aránya, és csupán $22 \%$ válaszolta azt, hogy előző lakása is kertes családi ház volt. Az 1995 után Nagykovácsiba érkezők között már csak 17\% volt a lakótelepekről, és $42 \%$ a sor- és tömbházakból kiköltözők aránya, a családi házukat otthagyók aránya viszont $30 \%$-ra nött.

\section{TÁBLÁZAT}

Az elözö lakóhely és a jelenlegi lakóhely jellemzöi a szuburbán bekölttözök válaszai alapján (az adott jellemzöt megjelölö szuburbán válaszadók százalékos aránya) (The Characteristic Features of the Former and the Present Domicile Based on the Answers of Suburban Settlers)

\begin{tabular}{lcc}
\hline \multicolumn{1}{c}{ Lakóhely jellemzöi } & $\begin{array}{c}\text { Elözö lakóhely } \\
(\%)\end{array}$ & $\begin{array}{c}\text { Nagykovácsi } \\
\text { lakóhely (\%) }\end{array}$ \\
\hline Munkahely/iskola jó elérhetősége & 75 & 35 \\
Nagyvárosi központ jó elérhetősége & 86 & 39 \\
Napi bevásárlásra alkalmas üzletek jó & 86 & 68 \\
elérhetősége & 83 & 22 \\
Jó tömegközlekedés & 38 & 91 \\
Sétálási lehetőség & 34 & 55 \\
Játszási lehetöség & 59 & 78 \\
Szomszédsági jó kapcsolatok & 35 & 87 \\
Tiszta, környezetileg nem terhelt lakóhely & 23 & 93 \\
Nyugodt lakókörnyezet & 47 & 45 \\
Kényelmes, városias lakókörnyezet & 58 & 80 \\
Magas komfortfokozatú lakás & 23 & 72 \\
Nagy alapterületủ lakás & & \\
\hline
\end{tabular}

Forrás: Saját számítás. 
A lakóhelyváltást magyarázó tényezők egyike az, hogy mit nyújt az előző és a jelenlegi lakás, lakókörnyezet a migrációban résztvevő számára. Az előző lakóhelyét a Nagykovácsiba költöző szuburbán telepesek 65\%-a érezte környezetileg terheltnek, 77\%-uk találta a lakást kicsinek, és kétharmaduk érezte úgy, hogy nem volt megfelelö sétálási, játszási lehetőség a gyerekek számára. Az új, nagykovácsi lakás vonatkozásában a beköltözők nagy többsége javuló lakókömyezetröl és emelkedő kényelemről tett említést. Válaszadóink szerint Nagykovácsi csak a közlekedés terén marad alul a korábbi, városi lakóhellyel való összevetés során (1. táblázat).

\section{Öslakosok és betelepülök}

A nagykovácsi őslakosok és a betelepülők sok tekintetben eltérően ítélik meg jelenlegi lakásukat, lakókörnyezetüket. Az eltérỏ vélemény hátterében az rejtőzik, hogy a község lakosságának e két csoportja eltérő lakáskörülményekkel, iskolai végzettséggel, közlekedési szokásokkal jellemezhető.

A megkérdezett őslakosok $24 \%$-a nem rendelkezik szakképzettséggel, vagy csak betanított munkás, ezzel szemben a szuburbán beköltözők csupán 4\%-a tartozik ugyanebbe a végzettségi kategóriába. Az eredeti falusiak 23\%-a szakmunkás, az újonnan érkezetteknek mindőssze 6\%-a. Az őslakosok 21\%-a bír felsőfokú végzettséggel, a beköltözők esetében ez az arány $66 \%$ !

A két társadalmi csoport közötti státusbeli/jövedelmi különbséget az iskolai végzettség mellett a lakásviszonyok is jelzik. Míg az újonnan betelepülő lakosok 62\%-a kétszintes, $15 \%$-a háromszintes lakásban él, az öslakosok esetében csak $38 \%$ büszkélkedhet kétszintes, és mindössze $8 \%$ háromszintes családi házzal. A régi nagykovácsiak szerényebb méretü házai általában idösebb épületek, ezzel szemben a rendszerváltás után beköltözök zöme - közel kétharmada - 1990 után épített házban él.

A két társadalmi csoport közlekedési szokásai is eltérỏek. A helyinek számító családok 36\%-a használ személygépkocsit a munkába járáshoz, 44\%-uk viszont kizárólag a tömegközlekedést veszi igénybe. Az új nagykovácsi lakosok $43 \%$-a válaszolt úgy, hogy kizárólag személygépkocsival jár munkába, és mindössze 14\% közlekedik csak autóbusszal. A szuburbán beköltözők számára a személygépkocsi a legfontosabb közlekedési eszköz, és úgy tünik a gépkocsira utaltság az új telepesek egymást követő csoportjainál egyre fokozódik. (Az 1985 és 1994 között érkezett családok 36\%-a használ kizárólag gépkocsit a munkába járás során, az 1995 után beköltözőknél ez az arány már $47 \%$ !)

\section{A lakóhely eltérő megitélése}

A felmérés talán legizgalmasabb eredménye: sikerült kimutatni a helyi és a beköltöző népesség eltérő lakóhely-, lakókörnyezet-értékelését.

A jelenlegi lakás, lakóhely értékelésekor a különbség az őslakosok és a beköltözők között több okra vezethető vissza. Egyrészt a bekőltözők anyagi körülményei 
vélhetően jobbak, ezért az új lakosok nagyobb aránya jellemezte jelenlegi lakóhelyét úgy, hogy nagy alapterületü és magas komfortfokozatú. A település közlekedési helyzete a másik olyan kérdéskör, amelyben szintén jelentős véleménykülönbséget fedezhetünk fel a helyiek és beköltözők között. Nagykovácsi régi lakosai ugyanis nem értékelték rossznak a falu elérhetőségét, közel kétharmaduk szerint a munkahely és a belváros (Moszkva tér) jól elérhető, szemben a beköltözők 35-39\%-os arányával. A napi bevásárlásra alkalmas üzletek elérhetősége tekintetében is pozitívabb kép élt az öslakosok fejében, 77\%-uk szerint ez optimális jelenlegi lakóhelyén; a beköltözőknél ez az arány csak $68 \%$. A helyi tömegközlekedésre szinte mindenki panaszkodott, de még e tekintetben is kevésbé volt negativ az őslakosok véleménye, csupán 57\%-uk vẻlte úgy, hogy rossz a tömegközlekedés, szemben a szuburbán népesség $78 \%$-os arányával. Érdekes eredmény az, hogy a helyi lakosok környezetileg kissé terheltebbnek érezték a lakóhelyüket $(2 . a ́ b r a)$.

A faluról alkotott mentális kép tehát némileg eltér az öslakosok és a betelepülők esetében. A régi nagykovácsiak zöme vidékröl költözött az agglomerációba, nekik Budapest központjának egy óra alatt való elérése nem számít soknak. Ugyanez elmondható a Nagykovácsiban felnőtt fiatalok esetében is, számukra ez az utazás megszokott, természetes lakóhelyi adottság. Az, hogy az öslakosok némileg kevésbé emelték ki lakóhelyük kedvező környezeti viszonyait szintén érthető, hiszen ők nem a kellemes lakókörnyezetért költöztek Nagykovácsiba, számukra ez kevésbé fontos. Persze az eredmények térbeli vonatkozásait sem szabad figyelmen kívül hagynunk. Az öslakosok által lakott településrészek ugyanis tényleg terheltebbek környezetileg (föutca), az új beköltözök által benépesített hegyoldalak némelyike pedig - távol esvén a falu központjától - valóban rosszabb közlekedési viszonyokkal jellemezhetö.

\section{2. ÁBRA}

Az őslakos és a beköltözö lakosság véleménye a jelenlegi lakóhelyéröl (az adott jellemzőt megjelölők százalékos aránya)

(The Opinion on the Present Domicile of the Original and the Suburban

\section{Inhabitants)}

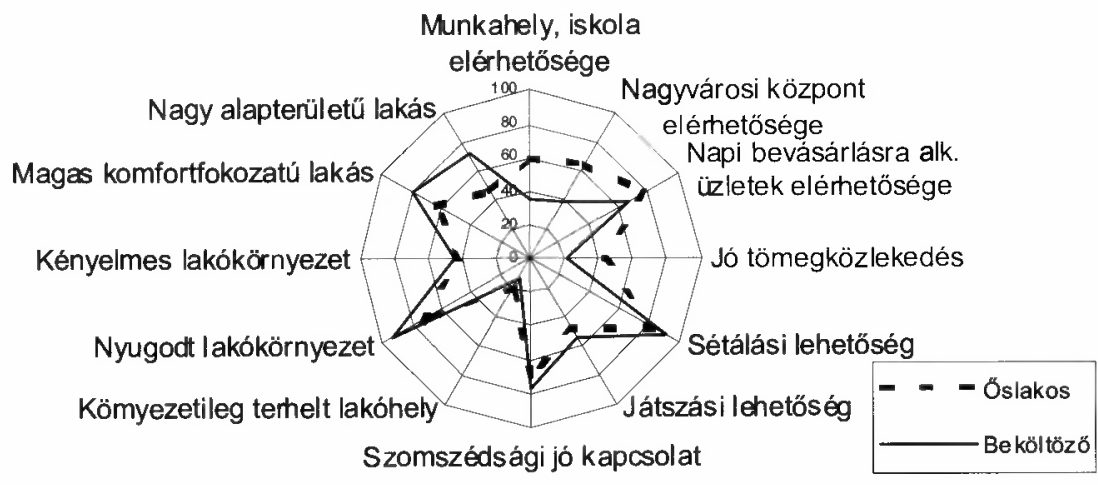

Forrás: Saját szerkesztés. 


\section{Menni vagy maradni?!}

A betelepülök és az öslakosok egyaránt úgy vélték, hogy Nagykovácsi olyan település, ahol kellemes élni. Csupán 11 válaszadó nyilatkozott úgy, hogy egyértelmúen rossz a lakásviszonya, illetve a lakókörnyezete. Az elégedettségnek köszönhetỏen kevés olyan válaszadóval találkoztunk, aki el kívánt költözni jelenlegi lakóhelyéről (42 fö). Sőt, az elköltözni vágyók fele is Nagykovácsiban kívánt új otthonra lelni, azaz a településen akart maradni. Budapestre csupán 14 család kívánkozott, melyek közül 11 szuburbán telepes volt, olyanok, akik nem találták meg Nagykovácsiban azt, amire a kiköltözés idején számítottak. (Ez akár a reurbanizáció halvány elöjele is lehet.) Az elköltözés indokaként a családi okokat jelöltek meg legnagyobb arányban a válaszadók, a második legfontosabb elköltözési ok azonban a háztartásokra nehezedö pénzügyi teher volt.

\section{Összegzés}

Nagykovácsi a fővárosi agglomeráció különleges földrajzi helyzetü települése. Budapest közelsége alapvetően befolyásolja a község életét, fejlődését. A zártkertparcellázások nyomán már az 1970-es években sok fövárosi lakos szerzett ingatlant a faluban, az 1980-as évek közepétől kezdve viszont már tömegesen költöztek a budapestiek Nagykovácsiba. A szuburbán betelepülések nyomán két évtized alatt majdnem megduplázódott a község lakossága, átformálódott a falu arculata. A beköltözők képzettsége, anyagi helyzete jobb az öslakosokénál. A betelepülők ugyanakkor nem képeznek homogén társadalmi csoportot, a kiköltőzők két hullámát érdemes elkülöníteni. Az 1990-es évek közepe elô̋tt érkezett szuburbán betelepülök jelentős része tömbházakból, lakótelepekröl érkezett a faluba, és ma is jobban rászorul a tömegközlekedésre. Az 1995 után beköltözők között viszont már sok a zöldövezeti kertes házból érkező, és az ő körükben a személygépkocsi kizárólagos használata sokkal jellemzőbb.

A községből alig akar valaki elköltőzni. Az őslakosok és a szuburbán betelepülók egyaránt elégedettek jelenlegi lakókörnyezetükkel. Mégis, a két csoportnak a faluról, a lakókőrnyezetről alkotott mentális képe jelentősen eltér. A különbség a település térbeli elérhetőségével kapcsolatban a leglátványosabb, az őslakosok szerint Nagykovácsiból minden viszonylag jól elérhető, a betelepülők viszont sokkal roszszabbnak látják a falu közlekedési helyzetét.

A felmérés idején a kőzség lakosságának közel felét még az őslakosok tették ki, akik sok jellemző tekintetében élesen elkülönültek a betelepülőktől (lakáskörülmények, végzettség, vélemény). Még láttuk a régi Nagykovácsit, de már kirajzolódott elöttünk egy új, magas státuszú szuburbán település képe. Az elkövetkező néhány évben a betelepülök aránya már egyértelmủen meg fogja haladni az öslakosokét, és a falu az átalakulás egy újabb szakaszába léphet. 


\section{Jegyzetek}

${ }^{1}$ A kérdőivezésben az ELTE Társadalom- és Gazdaságföldrajzi Tanszékének terepgyakorlatozó hallgatói is közreműködtek: Bacsó Szilvia, Balogh Attila, Csohány Borbála, Fülöp Zsófia, Győrfi Erika, Nemes Eszter, Szankó Gergö, Vancsó Veronika.

${ }^{2}$ Az 1941 -es népszámlálás alkalmával a lakosság $86,5 \%$-a vallotta magát német anyanyelvünek.

${ }^{3}$ Az ezredforduló idején a zártkerteket belterületbe vonta a települési önkormányzat.

${ }^{4}$ A két település lakóinak egyủttes száma 2005-ben 5991 fỏ volt. Nagykovácsié 5493, Remeteszőlősé 498 fố.

\section{Irodalom}

Bajmócy P. (2000) A „vidéki” szuburbanizáció Magyarországon Pécs példảján. - Tér és Társadalom. 2-3. 323-330. o.

Dövényi Z.-Kovács Z. (1999) A szuburbanizáció térbeli-társadalmi jellemzöi Budapest környékén. Földrajzi Értesitö. 1-2.33-57. o.

Hardi T. (2002) Szuburbanizációs jelenségek Györ környékén. - Tér és Társadalom. 3. 57-83. o. 